https://doi.org/10.5817/OS2020-1-1

\title{
Opera Slavica ve třicátém ročníku
}

Když jsme před 30 roky v úzkém redakčním kruhu začínali časopis Opera Slavica vydávat, nikdo z nás netušil, do čeho vlastně jdeme. Kdyby se nás někdo tehdy zeptal, jak dlouho časopis bude existovat, pravděpodobně bychom pokrčili rameny a spíše jako otázku vyslovili domněnku: Dva roky? Tři? Netušili jsme, že to bude nejméně třicet let, protože ročníkem 2020 skutečně vstupujeme do třicátého roku existence časopisu.

Časopis od té doby vyzrál - změnily se technické možnosti, proměnil se zpơsob př́pravy čísel; mnohé změny redakční rada udělat chtěla, jiné udělat musela, abychom vyhověli docela striktním požadavkům kladeným na recenzní řízení, komunikaci s autory, na otevřený přístup, ... Nebylo toho málo, co jsme v počátcích netušili, co ale přivedlo časopis na úroveň, na které v tuto dobu je, a to po obsahové i po grafické stránce.

Třicetiletá Opera Slavica mají už tradici, mají svůj rozšiřující se okruh autorů i odběratelů, mají mnohem širší redakční radu, doufáme, že mají už i své pevné místo mezi slavisticky orientovanými časopisy.

Třicet let časopisu je současně př́ležitostí podívat se do budoucnosti: čeká nás určitě nějaké další kolo všeobjímající digitalizace (i když potištěný papír voní a ruka na něm ráda spočine), blíží se doba generační výměny na pozicích výkonných redaktorů, hodláme určitě rozšiřovat okruh autorů, kteří budou s časopisem spolupracovat, zdokonalovat se bude nadále i technická příprava jednotlivých čísel časopisu. Doufáme ale, že se nebude měnit snaha a možnost tisknout podnětné texty na seriózní slavistická témata, že přibude autorů i čtenářů, kteří oceňují do jisté míry konzervativní snahu redakční rady nepodřizovat se konjunkturním tématům ani organizačním krokům podníceným dobovou náladou a administrativními přístupy, že snad za určitou řádku let oslaví časopis další půlkulaté a třeba i kulaté jubileum.

Za redakční radu děkujeme autorům, čtenářům i příznivcům časopisu Opera Slavica za věrnost a za spolupráci a těšíme se na jejich pokračování.

Josef Dohnal, Fiři Gazda, Ivo Pospišil

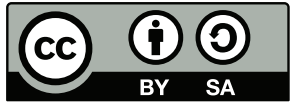

Toto dílo Ize užít v souladu s licenčními podmínkami Creative Commons BY-SA 4.0 International (<https:// creativecommons.org/licenses/by-sa/4.0/legalcode>). Uvedené se nevztahuje na díla či prvky (např. obrazovou či fotografickou dokumentaci), které jsou v díle užity na základě smluvní licence nebo výjimky či omezení príslušných práv. 
